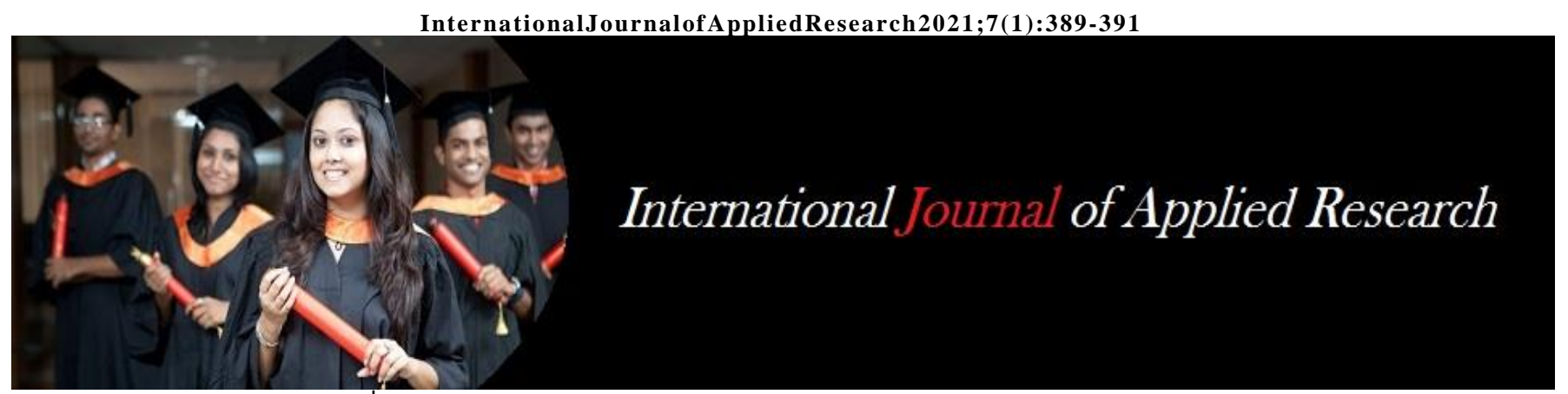

ISSN Print: 2394-7500 ISSN Online: 2394-5869 Impact Factor: 8.4 IJAR 2021; 7(1): 389-391 www.allresearchjournal.com

Received: 07-11-2020 Accepted: 09-12-2020

Shilpi Roy Choudhury Ex-Student of Department of Education, University of Kalyani Kalyani, Nadia, West Bengal, India
Corresponding Author: Shilpi Roy Choudhury Ex-Student of Department of Education, University of Kalyani Kalyani, Nadia, West Bengal, India

\section{Attitude of secondary school students towards continuous and comprehensive evaluation (CCE) in rural areas}

\section{Shilpi Roy Choudhury}

DOI: https://doi.org/10.22271/allresearch.2021.v7.i1f.8210

\section{Abstract}

The purpose of the research was to find out the attitude of the students in Rural Area (from both govt. aided \& private school) towards Continuous and Comprehensive Evaluation (CCE). 210 Secondary School Students have selected as sample through random sampling as sample from rural area in Murshidabad district. After collecting, analyzing and interpreting data, a significant difference has found from the research.

Keywords: CCE, govt. aided school \& private school, secondary school students

\section{Introduction}

Evaluation is the systematic collecting, analyzing and reporting of information about students' knowledge, attitudes, skills, intensions and/or behaviors regarding specific contents, issues and experiences. To reduce the pressure of assessment from the students and putting their all-round development in front, CCE got mandatory in Right to Education Act (2009). CCE helps to understand the teaching learning process and the ability of students.

\section{Objectives}

1. To find out the nature of attitude of Secondary School Students towards CCE.

2. To find out the difference of attitude towards CCE between govt. aided and private or self-financed school students.

\section{Literature Review}

1. AnshuBala Singh, Dr. Jarnar Ahmed (2017), they worked on their study titled 'A Study of Attitude towards Continuous \& Comprehensive Evaluation of Senior Secondary School Students in Relation to their Study Habits' and found that a significantly positive was present between habits of Senior Secondary School Students and attitude towards CCE.

2. N, Subramaniam, Mrs M. Kalaiselvi, (2019), they worked on their study titled 'Attitude towards Continuous and Comprehensive Education of High School Students' and found a difference among govt. aided and self-financed high school students' attitude towards CCE.

3. Avtar Singh, Jayesh Patel, Roshni Desai (2013), they worked on their study titled 'Attitude of Student Teacher towards Continuous and Comprehensive Education with reference to gender, caste and habitat' and found that students have favorable attitudes towards teachers, classroom behavior and method.

4. R. Sivakumar, S. Pazhanimurugan, Dr. A Edward William Benjamin (2011) worked on their study titled 'Students Attitude towards Continuous and Comprehensive Education of Upper Primary Schools' and found that there was a significant difference between students' attitude towardsContinious and Comprehensive Education of Upper Primary Schools. 


\section{Hypotheses}

${ }^{\mathrm{O}} \mathrm{H}_{1}$ - There is no difference in attitude towards CCE between Govt. Aided and Private or self-financed school students.

${ }^{\mathrm{O}} \mathrm{H}_{2}-$ There is no difference in attitude towards CCE between boy and girl students in govt. aided school.

${ }^{\mathrm{O}} \mathrm{H}_{3}$ - There is no difference in attitude towards CCE between boy and girl students in Self-Financed School.

\section{Method}

The type of the study is Quantitative Descriptive Survey type. Data has been analyzed by this study through inferential statistics, Mean, S.D. and ' $t$ '-test.

\section{Variable}

For this study two variables have been taken; type of school (Govt. \&Private) and gender (Boys \& Girls) respectively.

\section{Sample}

210 students have randomly selected as a sample from two Govt. Aided and two Self-Financed schools of Murshidabad district in West Bengal.

\section{Tool used}

To find out the attitude of Secondary School Students towards CCE, researcher has developed a tool and this tool has sent to expert and it has been standardized and validated by him (the expert).

\section{Analysis and Interpretation}

Analysis of data

Table 1: 't'-test: Attitude towards CCE between Govt. Aided and Private School Students

\begin{tabular}{|c|c|c|c|c|c|c|}
\hline & Number & Mean & S.D. & df & t-value & Significant Level \\
\hline Govt. Aided & 116 & 102.31 & 9.36 & & \multirow{2}{*}{208} & \multirow{2}{*}{0.34} \\
\hline Self-financed & 94 & 119 & 9.97 & & & 0.01 \\
\hline
\end{tabular}

*Significant at the 0.01 level

Table 2: 't'-test: Attitude towards CCE between boy and girlstudents of Govt. Aided Secondary School.

\begin{tabular}{|l|l|c|c|c|c|c|c|}
\hline & & Number & Mean & S.D. & df & t-value & Significant Level \\
\hline \multirow{2}{*}{ Govt. aided } & Boys & 72 & 102.25 & 11.88 & 114 & 20 & 0.01 \\
\cline { 2 - 8 } & Girls & 44 & 102.40 & 1.04 & & \\
\end{tabular}

*Significant at the 0.01 level

Table 3: 't'-test: Attitude towards CCE between male and female students of Private Secondary School

\begin{tabular}{|l|l|c|c|c|c|c|c|}
\hline & & Number & Mean & S.D. & df & t-value & Significant Level \\
\hline \multirow{2}{*}{ Private } & Boys & 43 & 113.98 & 8.24 & & \multirow{2}{*}{4.40} & 0.01 \\
\cline { 2 - 8 } & Girls & 51 & 123.23 & 9.38 & & & \\
\hline
\end{tabular}

*Significant at the 0.01 level

\section{Interpretation}

After the analysis of the t-test-

${ }^{\mathrm{O}} \mathrm{H}_{1}$ : The corresponding ' $\mathrm{t}$ ' value of ${ }^{\mathrm{O}} \mathrm{H}_{1}$ is 3.34 and this value is significant therefore the corresponding hypotheses is rejected.

So, it is inferred that there is a significant difference between the attitude of Govt. Aided and Private Secondary School Students towards CCE.

${ }^{\mathrm{O}} \mathrm{H}_{2}$ : The corresponding ' $\mathrm{t}$ ' value of ${ }^{\mathrm{O}} \mathrm{H}_{2}$ is 20 and this value is significant therefore the corresponding hypotheses is rejected.

So, it is inferred that there is a significant difference between the attitude of boy and girl students of Govt. Aided Secondary School towards CCE.

${ }^{\mathrm{O}} \mathrm{H}_{3}$ : The corresponding ' $\mathrm{t}$ ' value of ${ }^{\mathrm{O}} \mathrm{H}_{3}$ is 4.40 and this value is significant therefore the corresponding hypotheses is rejected.

So, it is inferred that there is a significant difference between the attitude of boy and girl students of Private Secondary School towards CCE.

\section{Findings}

Researcher formulated three null hypotheses and all the three null hypotheses got rejected. So, these things which found out from the study are -

i. There is a significant difference of attitude between Govt. Aided and Private School Students. ii. There is a significant difference of attitude between boy and girl students of Govt. Aided Secondary School.

iii. There is a significant difference of attitude between boy and girl students of Private Secondary School.

\section{Conclusion}

A difference has been found in attitude of students of Govt. Aided and Private Secondary School and a significant difference has also been found in gender wise attitude of them, and in both cases, the attitude is positive in nature. But by observing the Mean Score distribution of Govt. Aided and Private School Students, it can be said that the attitude of Private Secondary School Students towards CCE is comparatively better.

\section{Reference}

1. Singh A, Patel J, Desai R. Attitude of Student Teacher towards Continuous and Comprehensive Education with reference to gender, caste and habitat,Educationia Confab 2013;2(1)

2. Singh AB, Ahmed J. A Study of Attitude towards Continuous \& Comprehensive Evaluation of Senior Secondary School Students in Relation to their Study Habits, International Journal of Humanities and Social Science Invention 2017;6(9):33-35.

3. Sivakumar R, Pazhanimurugan S, Benjamin AEW. Students Attitude towards Continuous and Comprehensive Education of Upper Primary Schools, 
International Journal Of Applied Research 2011;3(12):174-175.

4. Subramaniam N,Kalaiselvi M. Attitude towards Continuous and Comprehensive Education of High School Students, Internal Journal of Innovative Research and Engineering and Multidisciplinary Physical Science 2019;7(4):1-2. 